\title{
PALEOMAGNETISM AND THE OROCLINE HYPOTHESIS
}

\author{
S. ELDREDGE, V. BACHTADSE and R, VAN DER VOO
}

Department of Geological Sciences, The University of Michigan, Ann Arbor, MI 48109 (U.S.A.)

(Received October 18, 1984; accepted December 18, 1984)

\section{ABSTRACT}

Eldredge, S., Bachtadse, V. and Van der Voo, R., 1985. Paleomagnetism and the orocline hypothesis. In: N.L. Carter and S. Uyeda (Editors), Collision Tectonics: Deformation of Continental Lithosphere. Tectonophysics, 119: 153-179.

Oroclines were originally defined by Carey as curved mountain belts which initially were straight, or at least straighter than they are today. In the last few years, the definition has been broadened to include any curved mountain belt, regardless of its original shape.

Since the occurrence of oroclinal bending is best recorded in the change of declination as a function of tectonic setting, paleomagnetic and structural data from six potential oroclines have been compiled and analyzed to determine the amount of rotation displayed by the change of paleomagnetic declination relative to the change in strike of the fold bett.

The arcuate belts investigated are: the Sicilian-Calabrian Arc and the Umbrian Arc of Italy, the Swiss portion of the Jura Mountains, the central portion of the Appalachian Mountains (from Pennsylvania to Virginia, U.S.A.), the Wyoming-Idaho overthrust belt of western North America and the Hercynides of Western and Central Europe.

The Jura Mountains and the Pennsylvania-Virginia portion of the Appalachians fail to show significant oroclinal bending. The Wyoming-Idaho belt shows a combination of rotated (possibly oroclinal) and unrotated thrust sheets.

In the Sicilian-Calabrian Arc significant oroclinal bending caused by the impingement of the Calabria-Peloritani nappes in the Late Tertiary can be demonstrated, while the Umbrian Are of similar age, in the Northern Apennines, also shows oroclinal bending on a smaller scale.

Hercynian Europe (the only belt included in which deformation of basement rocks can be demonstrated) shows oroclinal bending (at least $80^{\circ}$ ) as well as a marked original curvature $\left(70^{\circ}\right.$ ) in its western part.

Common to all the oroclines studied in this paper is the probable impingement of a rigid block or continental margin during the orogeny, causing subsequent deformation and bending of the fold belt.

\section{INTRODUCTION}

The term orocline was first defined by Carey (1955) as "an orogenic system which has been flexed in plan to a horse-shoe shape". In recent years the term has been used to describe any orogen of arcuate shape, regardless of its deformational history. 
This extension of the original term has arisen largely because of the difficulties in restoring the primary shape of mountain belts, and in determining if an orogen was originally linear, or at least less bent, than it is today. Recent years have shown paleomagnetism to be a powerful tool for reconstructing such a paleogeographical and structural history (Van der Voo and Channell, 1980).

From the bulk of curved mountain belts throughout the world, we have chosen six to analyze in this study that have a suitable data base for our purpose: the Calabrian and the Umbrian Arc of Italy, the Jura Mountains of Switzerland, the Appalachian Mountains of eastern and the Wyoming overthrust belt of western North America, and the European Hercynian mountain belt. The structural and paleomagnetic data from an area must meet several criteria before an orogen can be used in this study:

(1) The curvature of the orogen must be defined by a systematic change in the trend of fold-axes.

(2) Geographic and geological position of the rocks sampled must be well documented.

(3) If rocks of more than one age are used. appropriate reference declinations must be available.

(4) The remanent magnetizations must pass modern reliability criteria, and the age of magnetization established either by a fold test or by comparison of paleolatitude with the reference apparent polar wander path (Irving. 1977).

Based on theoretical considerations, three possible magnetic signatures can be expected in the analysis of arcuate mountain chains:

(1) If the belt had an originally curved shape, then the magnetic declinations should not correlate with the change in fold-axis trend, but remain parallel.

(2) If the belt had a linear configuration, and was subsequently bent, then the change in magnetic declinations should mimic the change in fold-axis trend on a one to one basis.

(3) Bending of a preexisting arcuate belt will lead to a smaller change in magnetic declination than in the trend of the fold-axis or strike direction.

\section{METHOD}

In order to quantify the variation in paleomagnetic direction as a function of regional change in structural trend, we use the linear regression technique. All paleomagnetic data have been transferred to uniform polarities wherever necessary to avoid ambiguities caused by dual polarities. The observed declinations $\left(D_{s}\right)$ are subtracted from the reference declination $\left(D_{\mathrm{r}}-D_{\mathrm{c}}\right)$. Thus, a clockwise rotation away from the reference gives a negative value, and a counterclockwise rotation gives a positive value. Where available, the stable magnetization of contemporaneous and undeformed rocks is used as a reference. If reliable paleopoles are not obtainable. then an average reference declination is chosen. The exact value of the chosen declination $\left(D_{\mathrm{r}}\right)$ is not critical, only that it is constant. For the purpose of this study 


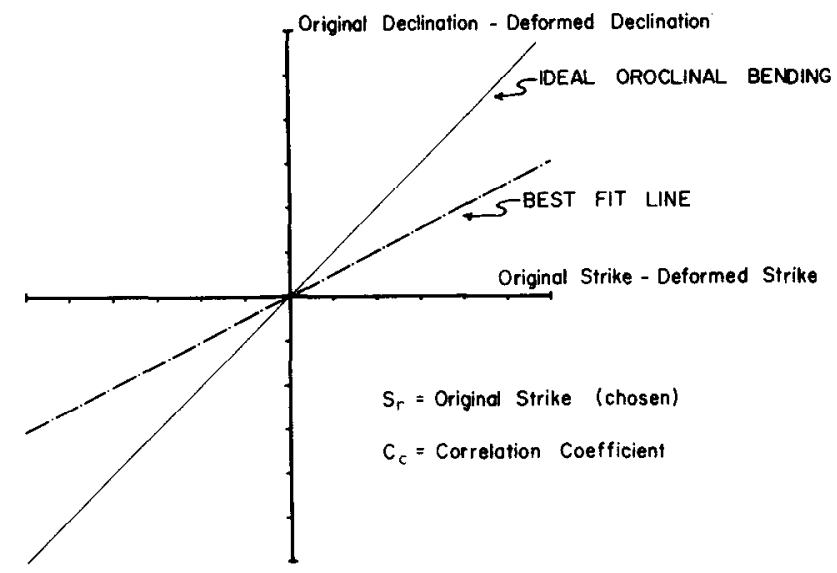

Fig. 1. Graphical comparison of change in strike vs. change in declination. Ideal oroclinal bending would display a line of unit positive slope. The best fit line is calculated by linear regression, and the correlation coefficient is for change in strike and change in declination. $S_{\mathrm{r}}$ is the estimated original strike of the orogen.

the paleomagnetic inclinations are of no importance, except to be used to calculate error limits $\left(\Delta D=\sin ^{-1}\left\{\alpha_{95} / \cos [\right.\right.$ Incl.] $\left.\}\right)$ on the declinations (Beck, 1980). These values might be too large (Demarest, 1983) but do not affect the results of our study.

The strike data are analyzed in a similar fashion to the declinations. The reference direction of strike $\left(S_{\mathrm{r}}\right)$ has been assumed as the average strike as determined by analyzing the shape of the arcuate orogen or to represent the primary trend of the orogen as a first approximation. The observed strikes $\left(S_{\mathrm{o}}\right)$ have been determined either from the original publications or from geological maps of appropriate scale.

The numerical values for $S_{\mathrm{r}}-\mathrm{S}_{\mathrm{o}}$ are plotted on the abscissa, and $D_{\mathrm{r}}-D_{\mathrm{o}}$ on the ordinate of an orthogonal coordinate system. When plotting the data set in such a fashion there are three endmember situations which can result (Fig. 1):

(1) If an orogenic belt displays perfect oroclinal behavior, then the data points should lie on the line of unit positive slope.

(2) If the orogenic belt contains parallel, nearly linear, thrust fronts, while it consists of thrust sheets that underwent various amounts of rotation, then the data points should run in the ordinate direction.

(3) If the belt has an original arcuate shape that has seen no tightening, then the data points should fall along the abscissa.

SICILIAN-CALABRIAN ARC

The Sicilian-Calabrian arcuate belt (Fig. 2) includes most of Sicily and the Southern Apennines of Italy, which are separated by the Calabria-Peloritani nappes of northeasternmost Sicily and the "toe" of the boot of Italy. The arcuate trend of 


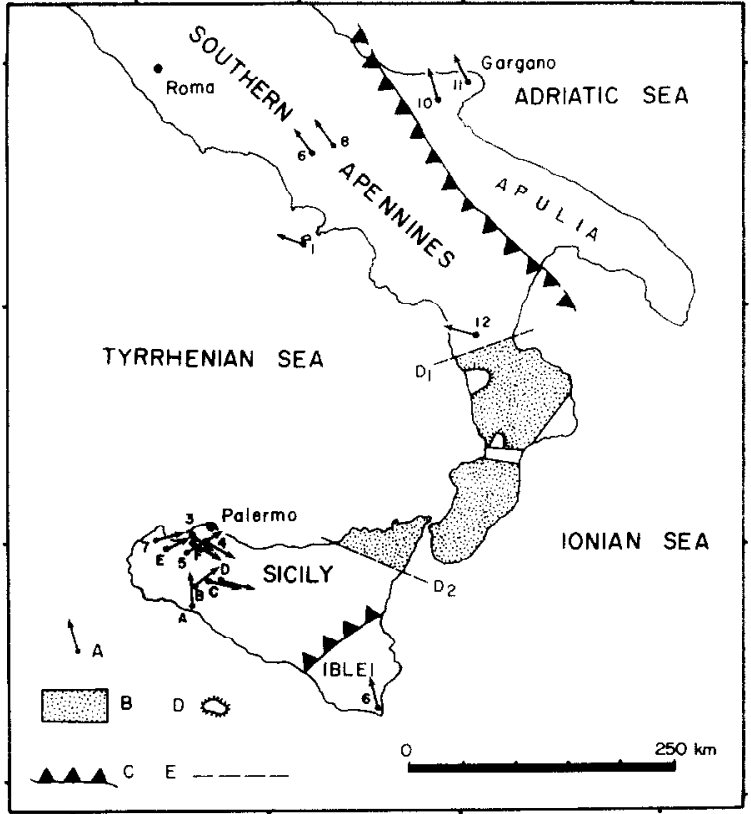

Fig. 2. Map of the Sicilian-Calabrian Arc, with arrows showing mean site declinations. Lettered sites are from Channell et al. (1980), while numerical sites are from Catalano et al. (1976). $A=$ mean site declinations; $B=$ Calabria-Peloritani nappes: $C=$ Overthrust front of the Apennines and Sicily nappes. teeth on the upper plate: $D=$ main tectonic windows (Apennines outcrop) in the Calabrian Peloritani arc: $E=$ transcurrent lines: $D_{1}$-Sangineto, $D_{2}$ - Taormina. Modified from Catalano et al. (1976).

the orogen is defined by the regional variation in the strike of fold axes and by the prevalent thrust fronts. These structures strike $\mathrm{N} 40^{\circ} \mathrm{W}$ and have a northeastern vergence in the Southern Apennines, and strike east-west with a southern vergence across Sicily. The thrust sheets consist of platform and basinal carbonates of Late Cretaceous age which originally formed parallel to the ancient southern Tethys margin (Bernoulli and Jenkyns, 1974). Only the Iblei zone in southeast Sicily, and parts of Apulia on the "heel" of Italy are considered to be autochthonous (cf. Channell et al., 1980). Paleomagnetic data for Upper Cretaceous basalts from the Iblei zone (Schult, 1973; Barberi et al., 1974; Gregor et al., 1975) as well as bauxites of the same age from Apulia are available in the literature (Channell and Tarling, 1975). Paleomagnetic data from contemporaneous rocks in these two autochthonous areas agree not only with each other (Schult, 1976), but with the apparent polar wander path of Van der Voo and French (1974) for Africa, implying that autochthonous Italy and Sicily are part of an African promontory. This relationship has been suggested by Channcll et al. (1979) and VandenBerg et al. (1978). Channell et al. (1980) further suggest that the Calabria-Peloritani nappes appear to be a discrete block thrust in the Miocene (Aquitanian) onto the carbonate platform.

Paleomagnetic studies throughout the Sicilian-Calabrian arc (Catalone et al., 
1976; Channell et al., 1980) concentrated on the Scaglia limestone of Late Cretaceous to Paleocene age. The characteristic magnetizations of these rocks pass the fold test and hence reflect pre-folding magnetizations.

The results from several Sicilian thrust sheets (Catalone et al., 1976; Channell et al., 1980) are compared with a reference declination $\left(D_{\mathrm{r}}\right)$ of $345^{\circ}$ determined from the autochthonous basalts of the Iblean foreland (Schult, 1973). The declinations from the allochthonous thrust sheets show a progressive clockwise rotation relative to Iblei, ranging from $10^{\circ}$ on the thrust sheet closest to the autochthon, to $140^{\circ}$ on the internal (northernmost) thrust sheet, near Palermo, northern Sicily (Fig. 2). The average strike of the Sicilian thrust fronts is east-west, and these are compared to an overall average strike for the orogen $\left(S_{\mathrm{r}}\right)$ of $\mathrm{N} 23^{\circ} \mathrm{E}$. The range in declination differences $\left(D_{\mathrm{r}}-D_{\mathrm{o}}\right)$ is much greater than strike differences $\left(S_{\mathrm{r}}-S_{\mathrm{o}}\right)$, causing the Sicilian portion of the plotted data to have an elongated distribution parallel to the ordinate direction (Fig. 3). This implies that Sicily itself has seen more rotation upon

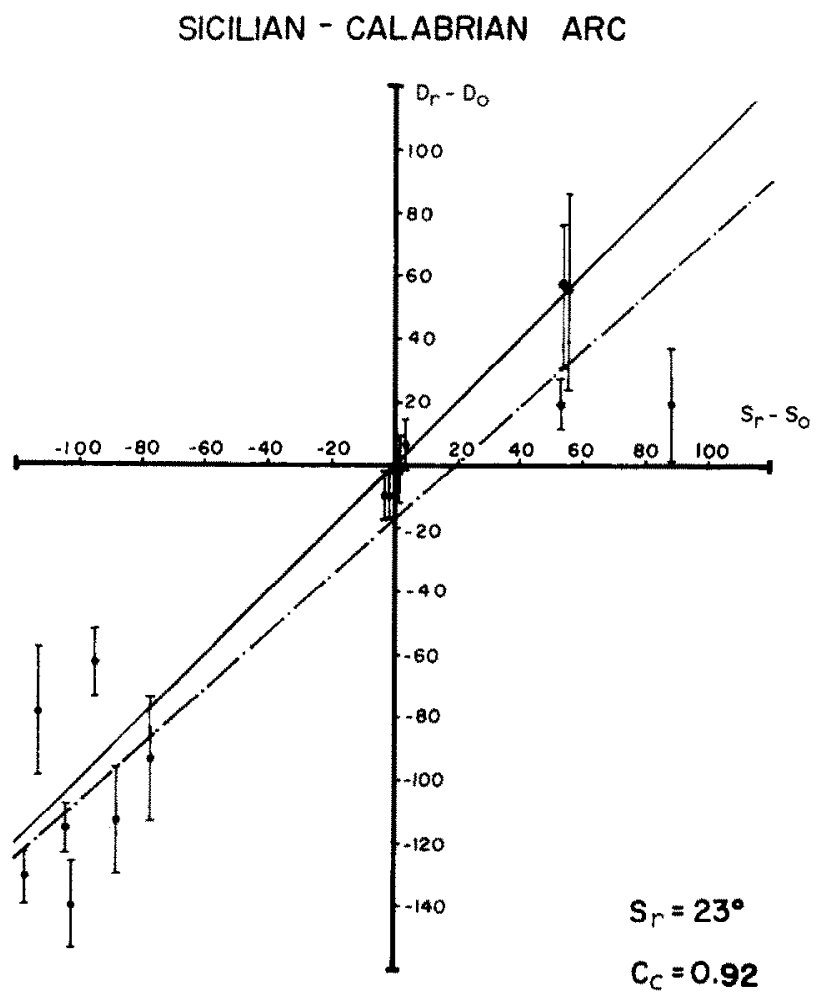

Fig. 3. Diagram showing the strike deviations relative to declination deviations for the Sicilian-Calabrian arc. $S_{\mathrm{r}}$ is the reference strike, $S_{\mathrm{o}}$ is the observed strike, $D_{\mathrm{r}}$ is the reference declination, and $D_{\mathrm{o}}$ is the observed declination. $C_{\mathrm{c}}$ is the correlation coefficient. Error bars calculated according to Beck (1980), see also text. Solid line with unit slope represents ideal oroclinal bending. Dashed line is a best-fit line calculated by linear regression. See Table 1 for numerical data. 
TABLE 1

Paleomagnetic data for the Sicilian-Calabrian Arc *

\begin{tabular}{|c|c|c|c|c|c|c|c|c|}
\hline Site & Locality & Strike & Ded. & Incl. & $S_{1}-S_{11}$ & $D_{\mathrm{r}}-D_{\mathrm{s}}$ & $\alpha_{45}$ & References \\
\hline \multicolumn{9}{|c|}{ Sicily } \\
\hline A & M. San Calogero & 23 & 355 & +35 & 0) & -10 & 7 & Channell et al. \\
\hline B & M. Genuardo & 108 & 48 & +40 & -85 & -63 & 8 & $(1980)$ \\
\hline $\mathrm{C}$ & $\begin{array}{l}\text { M. Barracu- } \\
\text { M. Colomba }\end{array}$ & 101 & 279 & -44 & -78 & -114 & 12 & \\
\hline $\mathrm{D}$ & M. Rose & 117 & 280 & -40 & -94 & -115 & 6 & \\
\hline $\mathrm{E}$ & M. Bonifato & 125 & 63 & +41 & -103 & -78 & 16 & \\
\hline$F$ & Sagana-Belmonte & 130 & 116 & +36 & $-\cdots-107$ & -131 & 36 & \\
\hline G & Terrasini & 115 & 125 & +38 & -92 & -140 & 11 & \\
\hline 6 & Iblei & 23 & 165 & -26 & 0 & 0 & 8 & $\begin{array}{l}\text { Barberi et al., } \\
\text { (1974) }\end{array}$ \\
\hline 7 & Custonaci & 90 & 75 & +28 & 67 & -93 & 17 & Schult (1976) \\
\hline \multicolumn{9}{|c|}{ Sowthern Apennines } \\
\hline 10 & Apulia Platform & 23 & 342 & +36 & 0 & 0 & 4 & Catalano et al. \\
\hline 11 & Gargano Basin & 23 & 335 & +38 & 0 & 7 & 7 & (1976) \\
\hline 8 & Matese & 320 & 322 & +28 & 63 & 20 & 7 & \\
\hline 6 & M. Maggiore & 255 & 322 & +31 & 98 & 20 & & \\
\hline 1 & Capri & 318 & 286 & +54 & 65 & 56 & 18 & \\
\hline 12 & M. Cerviero & 306 & 287 & +46 & 54 & 55 & 17 & $\begin{array}{l}\text { Manzoni (1975, in } \\
\text { Channell et al., } \\
1980 \text { ) }\end{array}$ \\
\hline
\end{tabular}

* $S_{\mathrm{r}}=23^{\circ}, D_{\mathrm{r}}=345^{\circ}$ (Sicily), $D_{\mathrm{r}}=342^{\circ}$ (Italy). Decl. and Incl. are declination and inclination in degrees. $\alpha_{95}$ is the radius of the cone of confidence at the $95 \%$ probability level (Fisher, 1953), $S_{\mathrm{r}}-S_{\mathrm{o}}$ is the reference strike minus the observed strike, $D_{\mathrm{r}}-D_{\mathrm{o}}$ is the reference declination minus the observed declination. $S_{t}$ was measured from regional maps.

décollement surfaces, probably consisting of Triassic evaporites (cf. Hsü and Bernoulli, 1978), than actual bending of the entire thrust system, including basement rocks.

The data from the Southern Apennines (Catalano et al., 1976) are less complete than the data from Sicily. Results are available for four sites in the allochthonous Southern Apennines, and two sites from the Apulian autochthon. Results of paleomagnetic surveys in the autochthonous Gargano region (Fig. 2) by Channell et al. $(1980)$ can be used as a reference declination $\left(D_{r}=342^{\circ}\right)$ for comparison with allochthonous southern Italy. The resulting normalized declinations $\left(D_{\mathrm{r}}-D_{\mathrm{o}}\right)$ show a counter-clockwise rotation ranging from $7^{\circ}$ to $56^{\circ}$ for the thrust sheets of the Southern Apennines (Table 1).

When the data are plotted according to the method of Schwartz and Van der Voo ((1983), a best fit line can be calculated by linear regression. This line (Fig. 3) falls nearly parallel to the line of ideal (i.e., unit slope) oroclinal bending (Fig. 1). The correlation coefficient $\left(C_{\mathrm{c}}\right)$ of 0.92 suggests strong correlation between the changes 
in declination and the changes in trend of the orogen, and therefore indicates oroclinal bending as the dynamic process responsible for the evolution of the Sicilian-Calabrian arc. Supporting evidence for our results has been enumerated by Catalano et al. (1976):

(1) Palinspastic restoration of the thrust sheets in the Southern Apennines and Sicily leads to stratigraphic overlap (unless bending is assumed).

(2) There is increased shortening in the sedimentary cover in both Sicily and Italy near the Calabria-Peloritani allochthon.

(3) The depth of burial (or metamorphic grade) of the sediments increases towards Calabria.

(4) The age of tectogenesis becomes older towards the Calabrian nappes.

(5) There are more internal units found near Calabria.

All of the evidence listed here, including the sense of rotations for the thrust sheets of Sicily and the Southern Apennines, is consistent with an Early Miocene impingement of the Calabria-Peloritani nappes and the synchronous oroclinal bending of the continental margin (Catalano et al., 1976).

\section{UMBRIAN ARC}

The Umbrian Arc is a convex-eastward Late Miocene-Pliocene orogen in the Northern Apennines of Italy (Fig. 4). The northern limb of the orogen trends NW, while the southern limb trends to the NNE, with fold axes throughout the orogen remaining roughly tangential to the arc. This area has been a subject of major paleomagnetic investigations in Italy since the mid 70's (Lowrie and Alvarez, 1975; VandenBerg and Wonders, 1976; Channell et al., 1978; VandenBerg et al., 1978), and there are several controversial interpretations of the results (cf. VandenBerg and Zijderveld, 1982). Notable among these interpretations is one by VandenBerg and Wonders (1976). These authors postulate that the whole Umbrian fold belt, together with its basement, has been rotated. This interpretation contrasts sharply with that of Channell et al. (1978), who explain the declination variations by systematic rotations of allochthonous sheets. We concur here with the second interpretation.

Paleomagnetic data are available for 51 sites in the basinal facies of the Scaglia Rossa limestone (Channell et al., 1978) of Late Cretaceous to Eocene age (Table 2). The magnetic results show a systcmatic variation in declinations from north to south which roughly parallels the change in trend of the orogen. Every site is dated paleontologically, and the changes in declinations can not be explained by variations in age (Channell et al., 1978). These data are best explained by some type of tectonic rotations about vertical axes.

It must be noted, however, that recent investigations on the paleomagnetism of Early Cretaceous limestones from Umbria by Hirt and Lowrie (1984) did not reveal this pattern of declination anomalies, but these results are as yet preliminary and only in abstract form. Numerical data for the Umbrian Arc are not directly available 


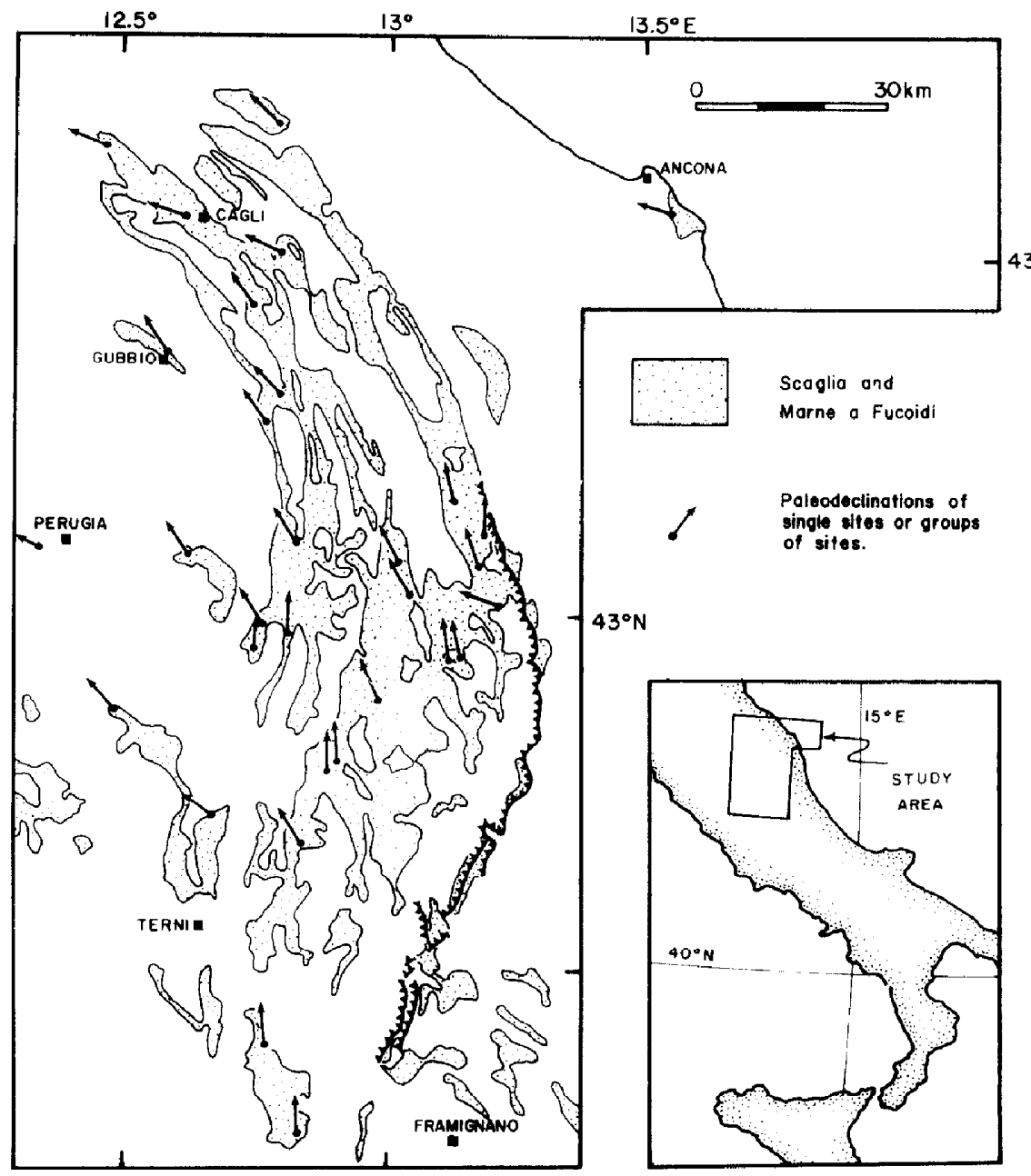

Fig. 4. Geological sketch map of the Umbrian Arc. The direction of paleodeclinations of individual sites or groups of sites are indicated by arrows (after Channell et al, 1978). Structural and paleomagnetic data have been measured from this map.

from the original publications and therefore had to be determined geometrically from sketchmaps in the publication of Channell et al. (1978, Fig. 4). As an illustration of the consequences of the choice of reference strike and reference declination, we will discuss our first attempt at analyzing the Umbrian data set. When the data were plotted with an average measured strike $\left(S_{\mathrm{r}}\right)$ of due north, the best fit line, calculated by least squares method, fell $20^{\circ}$ from the origin. By choosing a new $S_{r}$ of $339^{\circ}$, the best fit line retains, of course, the same slope but its trace is much improved and is now through the origin (Fig. 5). This suggests that if oroclinal bending did take place in the Umbrian Arc system, then the two limbs of the arc 
TABLE 2

Paleomagnetic data from Upper Jurassic blue micrites in the Jura Mountains *

\begin{tabular}{rrrrrrrl}
\hline Site & Strike & Decl. & Incl. & $S_{\mathrm{r}}-S_{\mathrm{o}}$ & $D_{\mathrm{r}}-D_{\mathrm{o}}$ & $\alpha_{95}$ & Reference \\
\hline 6 & 91 & 35 & +64 & -28 & -25 & 3 & Johnson et al. (1984) \\
7 & 74 & 216 & -59 & -11 & -26 & 17 & \\
8 & 75 & 15 & +59 & -12 & -5 & 6 & \\
9 & 73 & 15 & +60 & -10 & -5 & 8 & \\
17 & 58 & 19 & +65 & 5 & -9 & 4 & \\
19 & 73 & 3 & +47 & -9 & 7 & 13 & \\
30 & 73 & 358 & +47 & -11 & 12 & 5 & \\
31 & 97 & 18 & +46 & -34 & -8 & 7 & \\
32 & 96 & 9 & +54 & -33 & 1 & 4 & \\
33 & 76 & 312 & +65 & -13 & 58 & 5 & \\
35 & 68 & 30 & +49 & -5 & -20 & 22 & \\
36 & 50 & 4 & +61 & 13 & 6 & 8 & \\
39 & 53 & 0 & +57 & 10 & 10 & 10 & \\
40 & 52 & 11 & +52 & 11 & -1 & 9 & \\
41 & 55 & 336 & +61 & 8 & 34 & 12 & \\
42 & 73 & 7 & +53 & -10 & 3 & 13 & \\
43 & 72 & 16 & +44 & -9 & -6 & 17 & \\
44 & 73 & 15 & +57 & -10 & -5 & 14 & \\
45 & 74 & 1 & +54 & -12 & 9 & 6 & \\
46 & 82 & 22 & +35 & -19 & -12 & 6 & \\
47 & 90 & 356 & +64 & -27 & 14 & 10 & \\
48 & 89 & 350 & +55 & -25 & 20 & 9 & \\
49 & 81 & 22 & +61 & -18 & -12 & 15 & \\
52 & 103 & 23 & +47 & -40 & -13 & 12 & \\
\hline
\end{tabular}

${ }^{*} S_{\mathrm{r}}=63^{\circ}, D_{\mathrm{r}}=10^{\circ}$. See also Table 1 .

may not have seen an equal amount of rotation. It may be that the original trend of the orogen was closer to that of the northern limb, and that the southern limb has swung through a larger angle of rotation. This hypothesis is comparable with the change in structural style between northern and southern Umbria. Fold axes are more variable to the south (Channell et al., 1978), and the structures are generally more complex, possibly suggesting greater tectonic mobility in this region. These rotations may have occurred on a décollement surface in a Triassic evaporitic unit (Channell et al., 1978; Hsü and Bernoulli, 1978). With this structural interpretation, and the strong correlation between change in declination and change in strike, the Umbrian arc can properly be called an orocline. However, it must be noted that deformation does not include autochthonous Italy, and as such does not appear to involve lithospheric bending; in this, Umbria resembles the Sicilian-Calabrian Arc where the autochthonous basement (Iblei and Gargano) also shows no rotation. 
UMBRIAN ARC

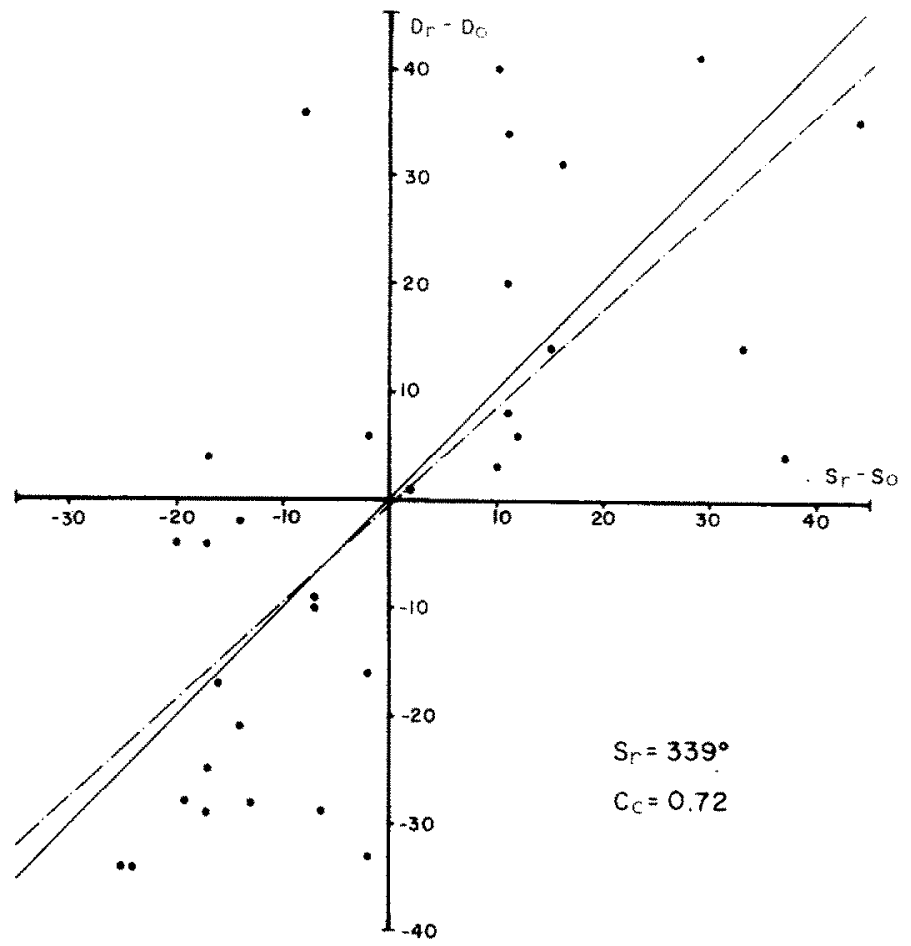

Fig. 5. Diagram showing the strike deviations relative to declination deviations (as in Fig. 3) for the Umbrian arc, $D_{\mathrm{r}}=329^{\circ}$.

\section{JURA MOUNTAINS}

The Jura Mountains form a gently arcuate belt, northwest of the Alps, in Switzerland and eastern France. The northern limb of the fold belt trends nearly $E$, while the southern limb trends NE. The orogen consists of largely Jurassic sedimentary rocks thrust in the latest Miocene (Laubscher, 1961) from SE to NW over a décollement in Triassic evaporites (cf. Rutten, 1969). Johnson et al. (1984) studied a series of Late Jurassic (Oxfordian-Kimmeridgian and Callovian) blue and tan limestones in the Jura (Table 3). Detailed paleomagnetic analysis suggests that the tan micrites carry a secondary magnetization and are diagenetically altered, but that the blue micrites appear to carry a primary magnetization. Statistical analysis of the site means determined for the blue micrites revealed a positive fold test (Johnson et al., 1984), significant at the 99\% confidence level (McElhinny, 1964).

The dataset from the blue micrites were analyzed and plotted with reference strike $\left(S_{\mathrm{r}}\right)$ of $63^{\circ}$. It must be noted that the sampling sites are distributed over a little more than half the entire belt; nevertheless there should be sufficient variation in strike to 
TABLE 3

Paleomagnetic data from the Pennsylvania salient and Virginia re-entrant in the Appalachian Mountains *

\begin{tabular}{|c|c|c|c|c|c|c|c|}
\hline Site & Strike & Decl. & Incl. & $S_{r}-S_{o}$ & $D_{\mathrm{r}}-D_{\mathrm{o}}$ & $\alpha_{9 s}$ & References \\
\hline JU 1 & 38 & 157 & +28 & -3 & 12 & 11 & Van der Voo and French (1977) \\
\hline JU 2 & 36 & 351 & -28 & -1 & -2 & 20 & \\
\hline JU 3 & 48 & 339 & -35 & -13 & 9 & 11 & \\
\hline JU 4 & 48 & 4 & -42 & -13 & -16 & 10 & \\
\hline JU 5 & 63 & 342 & -30 & -18 & 7 & 35 & \\
\hline JU 7 & 22 & 351 & -39 & 13 & -2 & 10 & \\
\hline JU 8 & 43 & 175 & +30 & -8 & -7 & 5 & \\
\hline JU 9 & 49 & 173 & +27 & -14 & -4 & 30 & \\
\hline $\mathrm{JU} 10$ & 49 & 341 & -47 & -14 & 8 & 37 & \\
\hline JU 12 & 34 & 349 & -37 & 1 & -1 & 29 & \\
\hline JU 13 & 22 & 193 & +22 & 13 & -25 & 14 & \\
\hline JU 14 & 35 & 154 & +32 & 0 & 15 & - & \\
\hline JU 15 & 55 & 164 & +33 & -20 & 5 & 24 & \\
\hline JU 16 & 48 & 173 & +34 & -13 & -4 & 12 & \\
\hline JU 17 & 43 & 349 & -18 & -8 & -1 & - & \\
\hline BL A & 72 & 24 & -23 & -37 & -24 & 10 & Roy et al. (1967) \\
\hline BL B & 81 & 2 & -30 & -46 & -2 & 10 & \\
\hline BLC & 82 & 0 & -28 & -47 & 1 & 14 & \\
\hline BL D & 82 & 4 & -28 & -47 & -4 & 5 & \\
\hline BLE & 49 & 343 & -34 & -14 & 17 & 14 & \\
\hline BL F & 49 & 0 & -29 & -14 & 1 & 5 & \\
\hline BL L & 23 & 336 & -37 & 12 & 24 & 4 & \\
\hline$B L M$ & 58 & 20 & -35 & -23 & -20 & 20 & \\
\hline BL $P$ & 87 & 353 & -24 & -52 & 8 & 6 & \\
\hline $\mathrm{CA} 2$ & 21 & 174 & +7 & 14 & -11 & 12 & Van der Voo et al. (1979) \\
\hline $\mathrm{CA} 3$ & 21 & 168 & -2 & 14 & -4 & 8 & \\
\hline CA 4 & 28 & 154 & +10 & 7 & 10 & 11 & \\
\hline CA 5 & 27 & 161 & +12 & 8 & 2 & 11 & \\
\hline CA 6 & 28 & 164 & +6 & 7 & 0 & 9 & \\
\hline CA 7 & 35 & 160 & +15 & 0 & 4 & 6 & \\
\hline CA 8 & 35 & 163 & +11 & 0 & 1 & 10 & \\
\hline RH 1 & 29 & 328 & -51 & 6 & 11 & 6 & French (1976), French (1978) \\
\hline RH 2 & 26 & 317 & -38 & 9 & 22 & 7 & French and Van der Voo (1977) \\
\hline RII $2 A$ & 27 & 335 & -45 & 8 & 4 & 15 & French and Van der Voo (1979) \\
\hline RH 4 & 45 & 11 & -49 & -10 & -32 & 14 & \\
\hline RH 5 & 47 & 343 & -46 & -12 & -4 & 14 & \\
\hline RH 11 & 49 & 329 & -30 & -14 & 10 & 14 & \\
\hline RH 17 & 33 & 353 & -27 & 2 & -14 & 14 & \\
\hline
\end{tabular}

* JU = Juniata, BL = Bloomsburg, CA - Catskill, RH = Rose Hill. Modified after Schwartz and Van der Voo (1983). $S_{r}=35^{\circ}, D_{r}$ varies with each formation, see text for details. See also Table 1. 


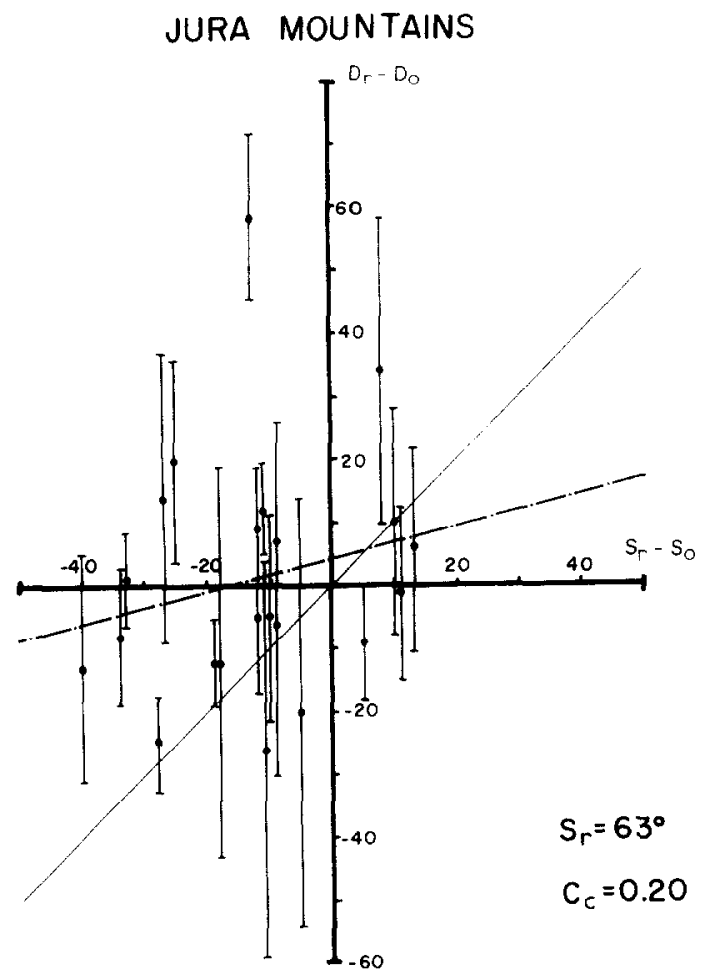

Fig. 6. Diagram showing the strike deviations relative to declination deviations (as in Fig. 3.) for the Jura Mountains. Note that reversed polarities have been inverted to normal. For numerical data see Table 2.

analyze for oroclinal bending. The regression line displays a far flatter slope than would be expected for oroclinal bending (Fig. 6), indicating that the orogen had an original arcuate shape. The correlation coefficient of 0.20 is indicative of the random scatter of the declination data with respect to the corresponding site strikes. This study suggests that the Jura Mountains cannot be described as an orocline because there is little evidence of post-depositional rotation in plan.

\section{APPALACHIAN MOUNTAINS}

In order to make our review more complete we summarize the results of an earlier analysis of a small portion of the Appalachian Mountains that has already been studied with respect to oroclinal bending by Schwartz and Van der Voo (1983). Only a small s-curved segment of the Appalachians between the Pennsylvanian salient and the Virginia re-entrant has been studied, and this displays a change in trend from $\mathrm{NE}-\mathrm{SW}$ in the north, through $\mathrm{N}-\mathrm{S}$, to NE-SW again in the south. Paleomagnetic data from four studies (Table 4) fullfilling the set of reliability criteria mentioned above are available at present: the Middle Silurian Rose Hill Formation (French, 
TABLE 4

Paleomagnetic data from the Wyoming-Idaho overthrust bclt *

\begin{tabular}{llrrrrrl}
\hline Site & Strike & Decl. & Incl. & $S_{\mathrm{r}}-S_{\mathrm{o}}$ & $D_{\mathrm{r}}-D_{\mathrm{o}}$ & $\alpha_{95}$ & Referencses \\
\hline \multicolumn{2}{l}{ Prospect thrust sheet } & & & & & & \\
$\mathrm{T}$ & 129 & 111 & -17 & 29 & 47 & 7 & Grubbs and Van der Voo, \\
$\mathrm{S}$ & 111 & 268 & +30 & 47 & 70 & 16 & $(1976)$ \\
$\mathrm{X}$ & 121 & 131 & -10 & 37 & 27 & 14 & \\
B & 160 & 9 & +23 & -2 & -31 & 5 & \\
$\mathrm{~J}$ & 170 & 155 & -25 & -12 & 3 & 8 & \\
$\mathrm{H}$ & 174 & 193 & -8 & -16 & -35 & 13 & \\
1 & 336 & 310 & +56 & -3 & 20 & 9 & Schwartz and Van der \\
& & & & & & & Voo (1984)
\end{tabular}

Darby and Absaroka thrust sheets

$\begin{array}{lrrrrrrl}\text { V } & 129 & 316 & +23 & 29 & 22 & 6 & \text { Grubbs and Van der Voo } \\ \mathrm{A} & 135 & 342 & +23 & 23 & -4 & 9 & (1976) \\ \mathrm{F} & 164 & 336 & +19 & -6 & 2 & 6 & \\ \mathrm{~K} & 164 & 157 & -8 & -6 & 1 & 11 & \\ \mathrm{D} & 158 & 146 & -16 & 0 & 12 & 7 & \\ \mathrm{E} & 158 & 321 & +13 & 0 & 17 & 6 & \\ \mathrm{C} & 183 & 163 & -11 & -25 & -5 & 14 & \\ 2 & 318 & 343 & +60 & 12 & -13 & & \text { Schwartz and Van der } \\ 3 & 324 & 329 & +47 & 6 & 1 & 14 & \text { Voo (1984) } \\ 4 & 318 & 310 & +57 & 12 & 20 & 5 & \\ 5 & 332 & 298 & +61 & -2 & 32 & 13 & \\ 6 & 352 & 318 & +73 & -22 & 12 & 4 & \\ 7 & 352 & 7 & +63 & -22 & -37 & 9 & \end{array}$

${ }^{*} S_{\mathrm{r}}=158^{\circ}$ for all sites, $D_{\mathrm{r}}=158^{\circ}$ for alphabetical sites, $D_{\mathrm{r}}=330^{\circ}$ for numerical sites. Observed strikes are measured from regional geologic maps, and sites 2 and 4 and sites 6 and 7 are averaged (Schwartz and Van der Voo, 1984). See text for stratigraphic units.

R.B., 1976; French, R.B. and Van der Voo, 1977; French, A.N., 1978; French, A.N. and Van der Voo, 1979), the Devonian Catskill Formation (Van der Voo et al., 1979), the Late Silurian Bloomsburg Formation (Roy et al., 1967), and the Ordovician Juniata Formation (Van der Voo and French, 1977). The different ages of the four formations require a different reference declination $\left(D_{r}\right)$ for each formation. Because there are few reliable paleopolcs available from cratonic North America, a reference declination has been selected based on the average for each age unit. An average strike $\left(S_{\mathrm{r}}\right)$ is measured as $\mathrm{N} 35^{\circ} \mathrm{E}$.

When the data are plotted by the standard method (Fig. 7), the line of best-fit shows a very poor relationship to the ideal oroclinal bending line, and a correlation coefficient of 0.34 shows that the changes in strike and the changes in declination are probably not related. Schwartz and Van der Voo (1983) have interpreted these data and concluded that the Pennsylvanian Salient-Virginia re-entrant transition in the Appalachians does not. display oroclinal bending. It is possible that the curvature in 


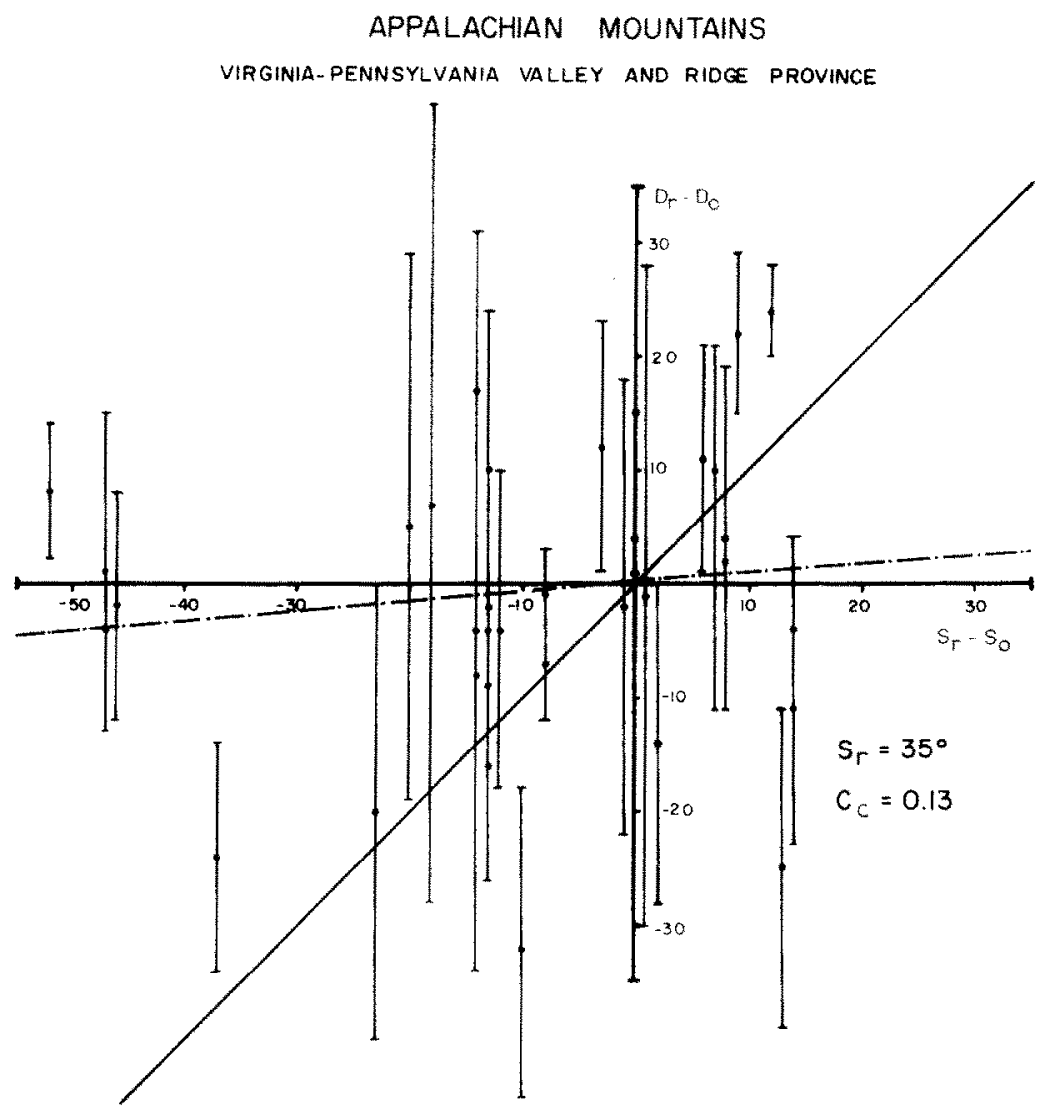

Fig. 7. Diagram showing the strike deviations relative to declination deviations (as in Fig. 3) for the Pennsylvania salient and Virginia re-entrant of the Appalachian Mountains. All normal polarities have been inverted to reversed. For numerical data see Table 3.

this area is a result of an original irregularity in the cratonic margin, e.g., an ancient embayment of the Iapetus Ocean, that was present before collision and subsequent deformation. This theory is upheld by several authors (Fleming and Sumner, 1975; Rogers, 1975; Rankin, 1976; Thomas, 1977). Further work is being done in other portions of the Appalachians in an effort to unravel the deformational history of a more complete section of the orogen (see also Alterman, 1984).

\section{WYOMING OVERTHRUST BELT}

The Wyoming-Idaho overthrust belt displays a pronouneed change in trend that is convex eastward in the region southwest of the Teton and the Gros Ventre Ranges and west of the Game Hill reverse fault (Fig. 8). This portion of the Rocky Mountain orogen consists of at least three major, eastwardly verging, thrust sheets: 


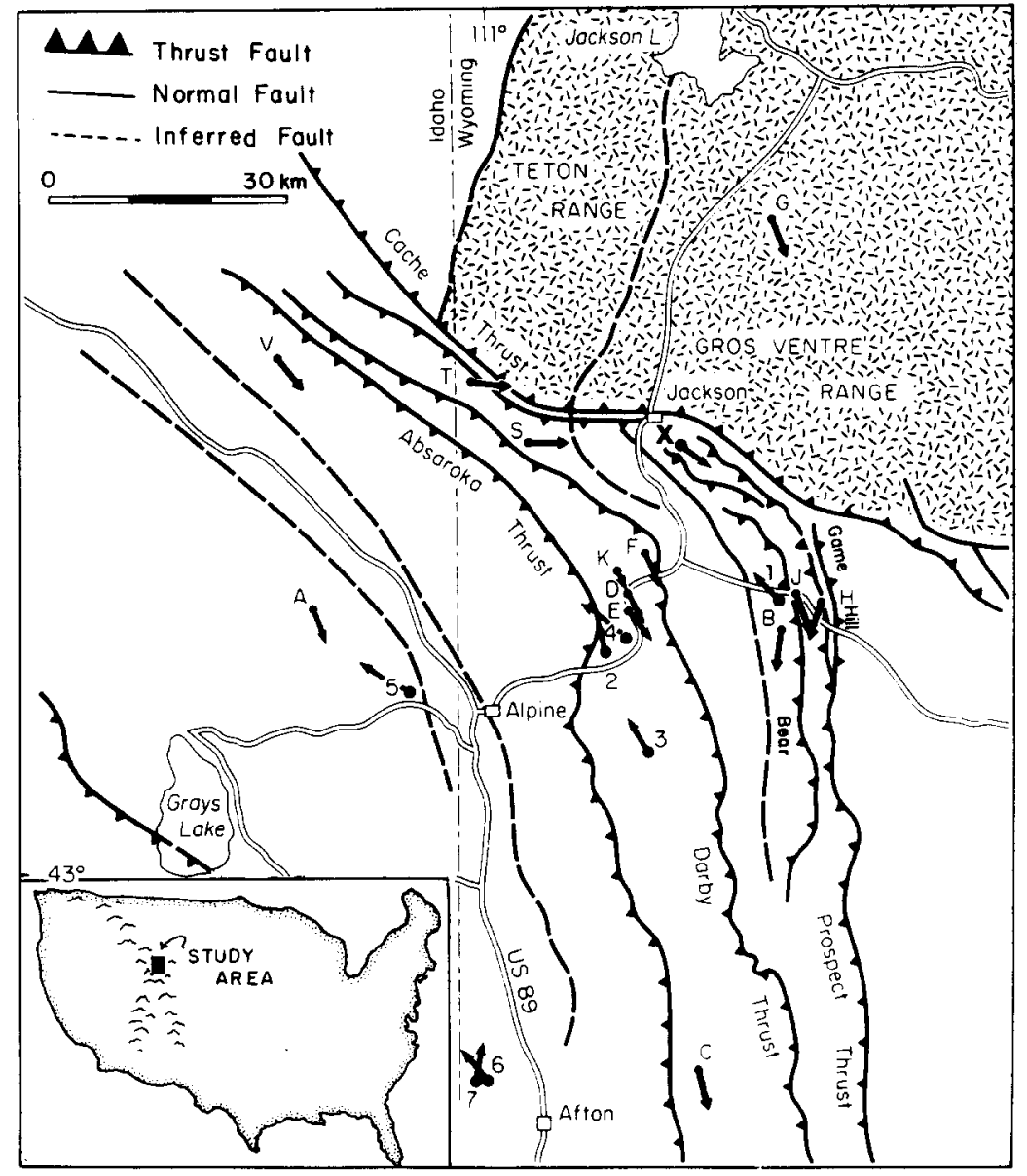

Fig. 8. Map of the Wyoming-Idaho overthrust belt. Numbered sites are Jurassic locations (Schwartz and Van der Voo, 1984) and lettered sites are Triassic sites (Grubbs and Van der Voo, 1976). Arrows show site-mean declinations, declinations from Jurassic sites are reversed relative to the Triassic sites. Site $G$ lies in the stable foreland, and its declination is used as a Triassic reference declination. Modified from Schwartz and Van der Voo (1984).

the Prospect, the Darby, and the Absaroka. These rocks have been deformed in the Late Mesozoic to Early Tertiary Sevier orogeny, during which thrusting progressed from west to east with older thrust sheets overlying the younger. Thus movements of the young frontal thrust sheets carried the older sheets "piggy-back" with them. Two paleomagnetic analyses of rotations have been undertaken in this region (Table 5). The first study (Grubbs and Van der Voo, 1976) sampled 14 sites in Triassic redbeds found mostly in the easternmost thrust sheets, while a later study by Schwartz and Van der Voo (1984) added data from seven Jurassic sites in the western sheets.

The Triassic data are available for the Ankareh, Chugwater, and Woodside 


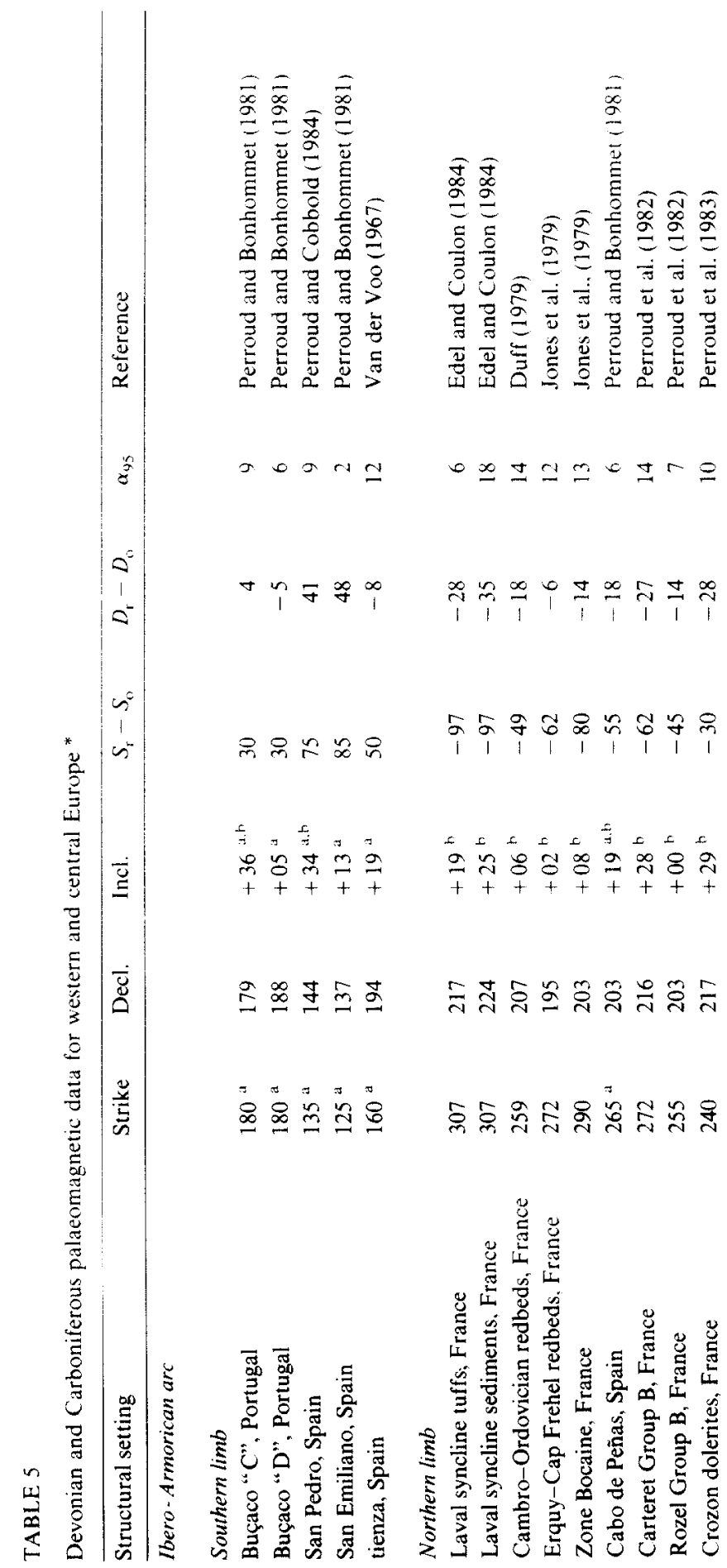




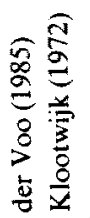

渮

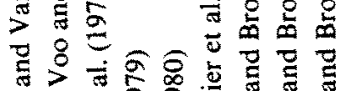

눙 崩

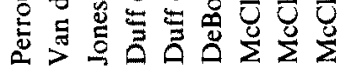

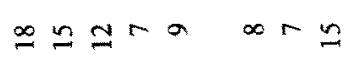

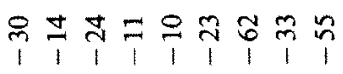

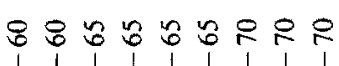

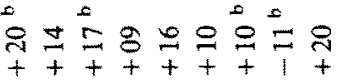

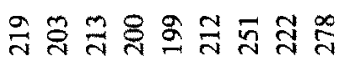

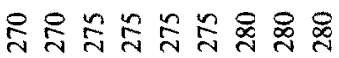

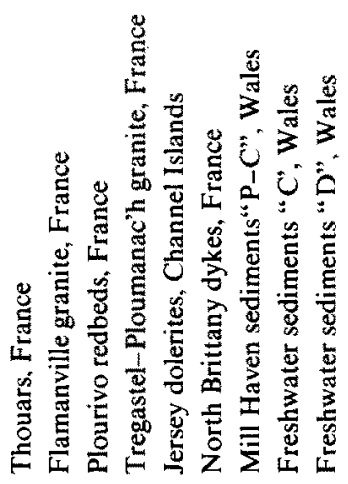

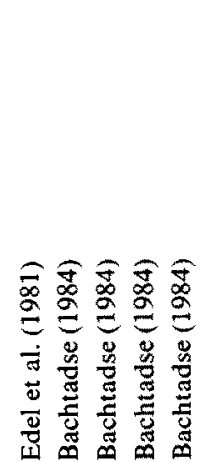

$\simeq \infty \stackrel{x}{\simeq}$

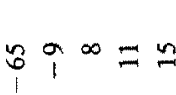

in 육유융ㅇ

$\begin{array}{lllll}1 & 1 & 1 & 1\end{array}$

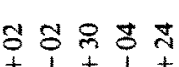

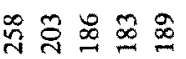

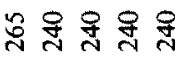

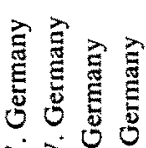
$3 \geqslant 3$

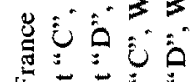

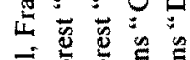

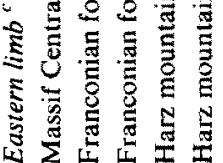

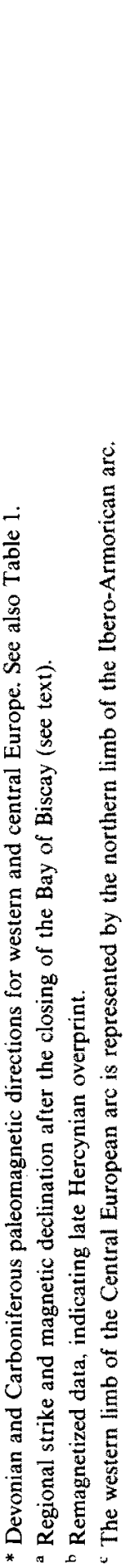


Formations (Grubbs and Van der Voo, 1976), and display stable, pre-folding, magnetizations. The reference declination $\left(D_{\mathrm{r}}\right)$ of $158^{\circ}$ was calculated for the average of three Triassic sites from the stable foreland (Grubbs and Van der Voo. 1976). A reference strike $\left(S_{\mathrm{r}}\right)$ or $158^{\circ}$ was found to be the most representative value and by coincidence this value is identical to the Triassic reference declination (Schwartz and Van der Voo, 1984).

The Jurassic rocks from the Oxfordian Stump Formation display stable magnetizations, and they also pass the fold test (Schwartz and Van der Voo, 1984). A reference declination of $330^{\circ}$ was taken from the contemporaneous and undeformed Jurassic Morrison Formation sampled in the Colorado Plateau (Steiner and Helsley, 1975 ) and the same reference strike $\left(S_{\mathrm{r}}\right)$ of $158^{\circ}$ was used (Schwartz and Van der Voo, 1984).

All data from the Prospect thrust sheet are plotted on Fig. 9a. Linear regression results in a significant correlation coefficient of 0.85 as well as a regression line that is approaching ideal oroclinal bending. On the other hand, for the data from the Darby and Absaroka sheets (Fig. 9b), the correlation coefficient is 0.34 , and the best fit line does not correspond well to ideal oroclinal bending. As the Prospect thrust is

\section{WYOMING OVERTHRUST BELT}

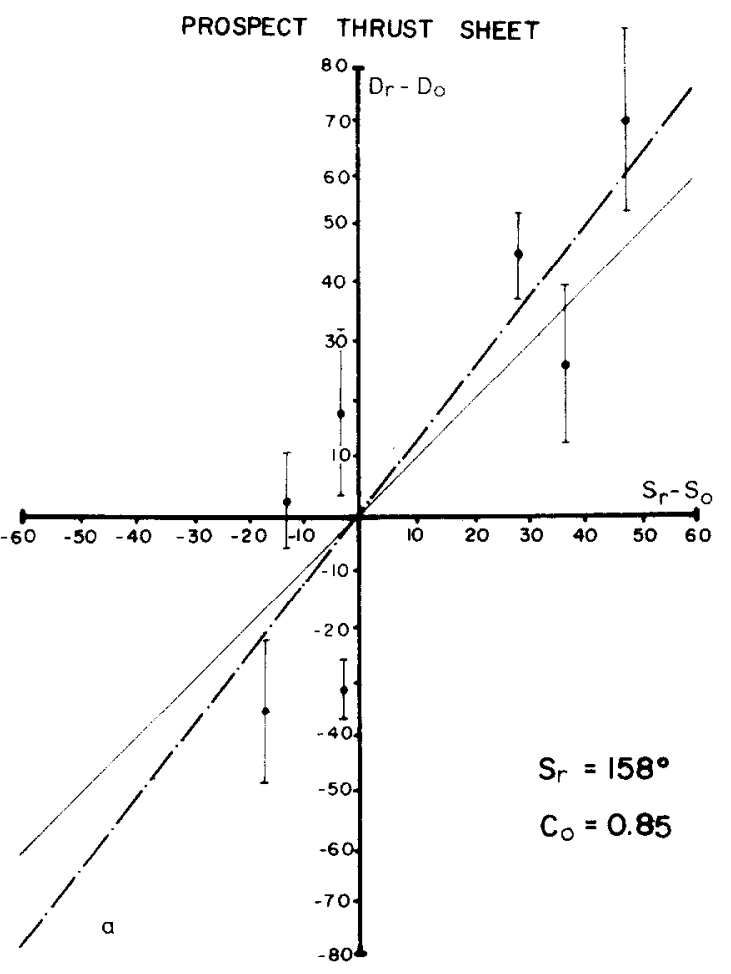




\section{WYOMING OVERTHRUST BELT}

DARBY AND ABSAROKA THRUST SHEETS

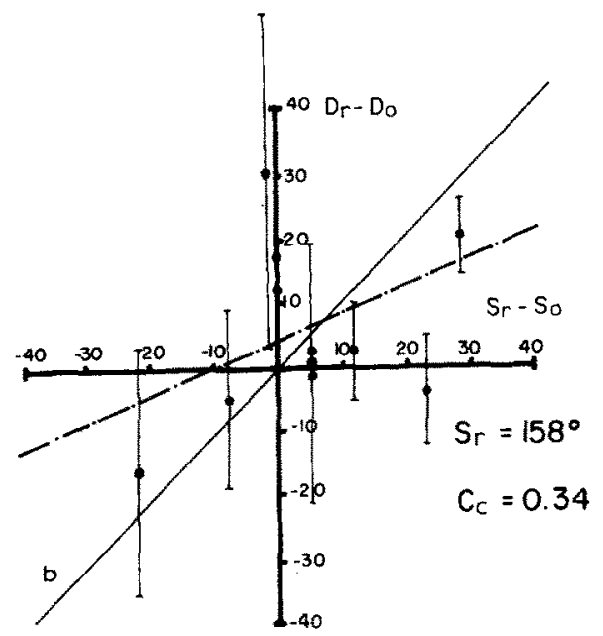

Fig. 9. Diagrams showing the strike deviations relative to declination deviations (as in Fig. 3). a. For the Prospect thrust sheet of the Wyoming thrust belt. b. For the Darby and Absaroka thrust sheets in the Wyoming overthrust belt. For numerical data see Table 4 . Strike data are measured from regional maps (Schwartz and Van der Voo, 1984).

the youngest thrust in the belt, any rotational bending that the Prospect sheet has undergone should have been transmitted to the overlying, older thrust sheets. As can be seen from the graphs, this is not the case. The interior of the thrust belt shows no systematic variation in declination, and this diminishes the likelihood that the Wyoming-Idaho thrust belt can be termed an orocline. Detailed structural work in the area suggests that the rotations seen in the Prospect thrust sheet are actually local rotations caused by the crumpling of the frontal edge of the thrust belt as the sheets were pushed against the ancestral Teton and Gros Ventre uplifts (Grubbs and Van der Voo, 1976; Schwartz and Van der Voo, 1984).

\section{THE EUROPEAN HERCYNIDES}

The European Hercynides between Poland in the northeast and Portugal in the southwest are represented by an irregularly shaped mountain belt of approximately $6000 \mathrm{~km}$ length. The sedimentary and structural history has been studied in great detail (cf. Rutten, 1969) and is well known.

The mountain belt itself consists of a central crystalline ridge containing Hercynian syn- and post-orogenic granites and Precambrian and lower Paleozoic rocks, reactivated and metamorphosed by Hercynian high-temperature low-pressure meta- 
morphism (Zwart and Dornsiepen, 1978). The internal crystalline ridge is bordered on both sides by fold belts consisting of low grade metamorphosed Paleozoic sediments and volcanics. The main Hercynian deformational events can be dated between late Visean to Westphalian (cf. Windley, 1984).

The Hercynian fold belt is characterized by a complex arcuate shape (Fig. 10). Excluding the curvature of the mountain belt southwest of the Tornquist line at the boundary between the stable Russian platform and mobile Europe, its arcuate shape can be defined by the change in structural trend from the so-called Variscan direction (NE-SW) of central Europe to the western European Armorican direction (NW-SE) in the Massif Central of France, lollowed by the strong curvature of a western branch around the Bay of Biscay which gives rise to the Ibero-Amorican structural arc. There is approximately $30^{\circ}$ of curvature in the Massif Central and the Ardennes. After restoring the pre-Mesozoic paleogeography around the Bay of Biscay by rotating the Iberian peninsula about $35^{\circ}$ clockwise (Van der Voo, 1969) around an Eulerian pole located in the western Pyrenees (Carey, 1955: Ries, 1978) the curvature resulting from the structural coherence of the Paleozoic of Britanny and the Iberian peninsula totals $165^{\circ}$ (Ries and Shackleton, 1976).

Several models have been proposed during recent years in order to explain the arcuate shape of the Hercynian orogen. Argand (1924) and Carey (1955) originally recognized the curvature of structural elements around the Bay of Biscay and Carey postulated secondary processes leading to the deformation of an originally straight fold belt. In more recent times. Ries and Shackleton (1976). Perroud and Bonhommet (1981), Lorenz (1976), Lorenz and Nicholls (1984) and Ziegler (1984) interpreted the irregular shape as the result of the accretion of one or several microplates onto the irregularly shaped continental margin of the North American-North European continent and the subsequent tightening of pre-existing structures during the final stages of the Hercynian collision (Perroud and Bonhommet, 1981). Implying a different tectonic setting, Arthaud and Matte (1977) postulated the rotation of discrete continental segments along huge strike-slip systems in a Late Carboniferous--Early Permian dextral shear system between the Urals and Appalachians. Lefort and Van der Voo (1981) used the similarities in structural evolution of the Hercynides and the Himalayas (Molnar and Tapponnier, 1977) to propose an indentation by the West African Shield into eastern North America and western Europe causing subsequent displacement and deformation of the eastern part of the Hercynides analogous to the peri-Himalayan structural setting.

Devonian and Carboniferous paleomagnetic data from the autochthonous and parautochthonous rocks of Hercynian Europe are now available for the central and western part of the fold belt (Table 5; Fig. 10). These data enable us to test the type of deformation of the orogen. The reference declination has been calculated for the different regions analyzed from the Late Carboniferous pole position for stable Europe $\left(41^{\circ} \mathrm{N}, 166^{\circ} \mathrm{E}\right)\left(\right.$ French, 1976). A reference declination $\left(D_{r}\right)$ for the Early Devonian of Wales (McClelland Brown, 1983) has been calculated from the Siluro- 


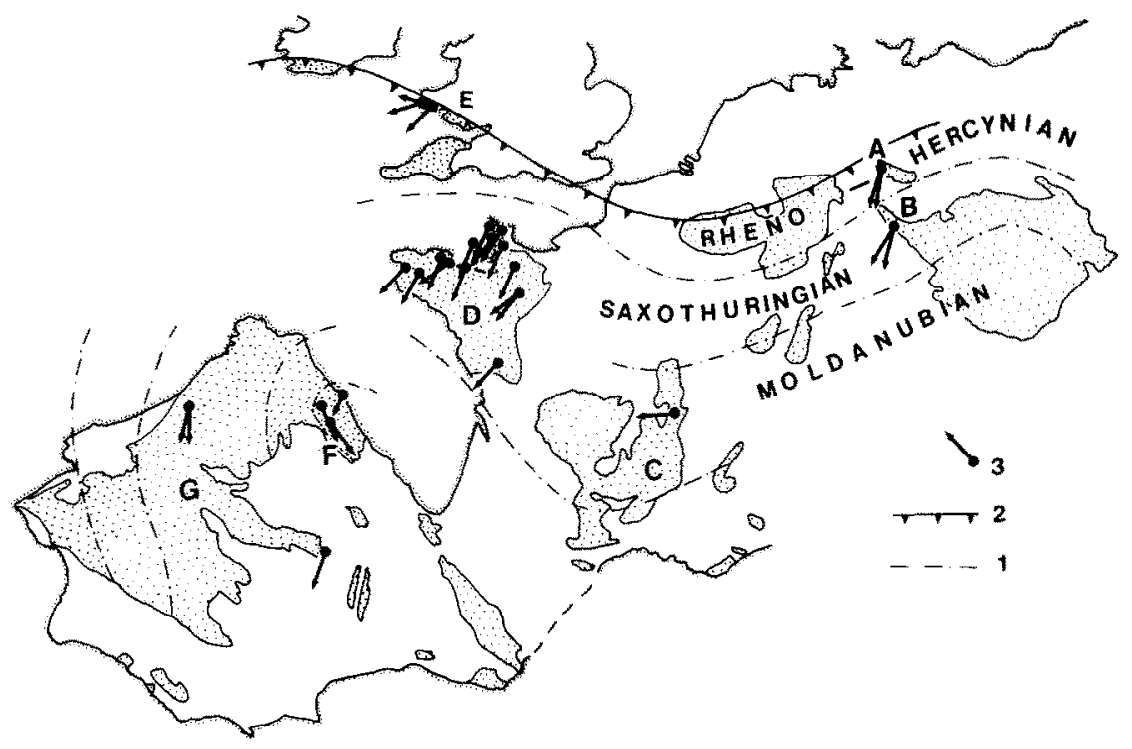

Fig. 10 Geological sketch map of the European Hercynides (after closure of the Bay of Biscay - Van der Voo, 1969) showing the direction of structural trends $(I)$, the northern overthrust $(2)$ and the directions of Devonian to Carboniferous (3) magnetic declinations (see also Table 5). Major Paleozoic massifs are stipled. $A$-Harz mountains; $B$-Franconian Forest; $C$ - Massif Central; $D$-Britanny; $E-$ Wales; $F$ - Cantabria; $G$-Calicia-Castilla.

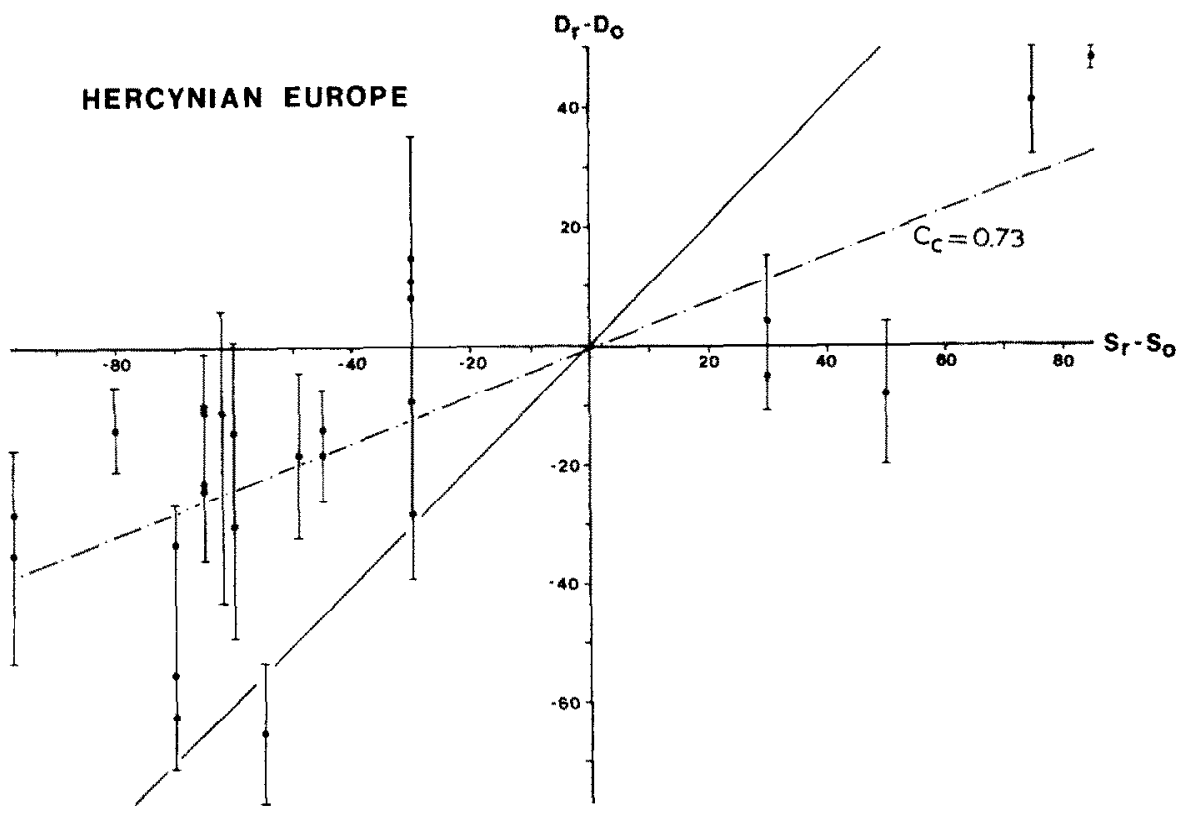

Fig. 11. Graph of strike deviations relative to declination deviations (as in Fig. 3) for Hercynian Europe. Dashed line is the best fit line calculated using linear regression. For numerical data see Table 5. 
Devonian pole position (Duff, 1980). A strike direction of $210^{\circ}$ has been chosen as reference strike $\left(S_{\mathrm{r}}\right)$. Linear regression reveals a reasonably high $(0.72784$ for $N=28$ ) correlation coefficient and suggests a strong relation between change in strike and declination. The slope of the line of regression, however, is lower $\left(21^{\circ}\right)$ than expected for perfect oroclinal bending and differs significantly from the reference line with unit slope (Fig. 11). The flattening of the regression line can be explaincd as the consequence of less intense tightening of the Ibero-Armorican are than would be implied by its present curvature. This observation is consistent with the results of Perroud and Bonhommet (1981) who showed that $70^{\circ}$ of structural curvature are of primary, pre-Hercynian, origin, whereas at least $80^{\circ}$ of rotation are of post-Early Carboniferous age and can be ascribed to the secondary tightening of a pre-existing and already curved fold belt during the Hercynian collisions in western Europe. These results support the oroclinal concept for the bending of the European Hercynides and suggest the bending is the result of either indentation or tangential stressfields.

\section{CONCLUSIONS}

Of the six arcuate deformed belts that we have analyzed in this study, at least three show significant evidence of oroclinal bending. The Jura Mountains fail the "orocline test", and the variations in declinations that can be seen are probably due to local deformation rather than a systematic rotation in plan. The arcuate nature of the belt can be explained by an original curvature that was present when the Jurassic carbonates were deposited, which was subsequently compressed uniformly along strike during the Alpine orogeny. The Pennsylvania salient and the Virginia re-entrant of the Appalachian Mountains also fail the paleomagnetic criteria for oroclinal bending. Here the arcuate nature of the belt can best be explained by irregularities in the cratonic margin prior to the collision of North America and Africa. The Wyoming overthrust belt has a curvature that can be explained only by a combination of processes. Certainly the frontal portion of the thrusted rocks appears to have undergone systematic rotation, albeit on a local scale. The ancestral Teton and Gros Ventre Ranges as well as the Game Hill reverse fault probably acted as buttresses that impeded the forward progress of the thrust sheets. These allochthons did not react by rotating as an entity, but rather crumpled at the frontal edges. giving an appearance of oroclinal bending for the Prospect thrust sheet. The question still remains as to the cause of the arcuate thrust traces west of the Prospect. One explanation, which seems unlikely, is that the sheets were originally more extensive than today but have undergone differential erosion. effectively stripping of the cover to the north, giving the thrust traces an arcuate exposure. A more likely explanation is that the rocks broke along an irregular line and were thrust without significant rotation into their present position.

The three other belts show significant evidence of oroclinal bending. The 
Sicilian-Calabrian belt definitely displays systematic rotation of thrust sheets toward the middle of the arc, in addition to other evidence (outlined earlier) in favor of a secondary curvature. The arcuate trend of the Umbrian arc is not nearly as pronounced as in the Sicilian-Calabrian arc, but it also displays a systematic, although asymmetric, rotation of paleomagnetic declinations that is evidence for oroclinal bending. The Hercynian belt is in a different class of orogens than the Sicilian and Italian arcs, being much larger in extent as well as more pervasive in effect. In the Hercynian belt, moreover, the lithospheric basement seems clearly involved in the large-scale bending. Although Hercynian Europe displays a great geologic complexity, the paleomagnetic data utilized here shed some light on the deformational history of the belt, suggesting oroclinal bending as a contributing cause of present-day geometries.

Simply stating that an orogen has undergone oroclinal bending does not provide answers to all the questions pertaining to the causes of its deformational history. There are several different processes that can be called upon to produce oroclines:

(1) compressional stresses and "buckling";

(2) ball bearing effects in megashear zones (Van der Voo and Zijderveld, 1969; Beck, 1976);

(3) impingement of a hitherto straight zone against a rigid and irregular margin, causing indentation;

(4) radial emplacement off a rising highland.

The Sicilian-Calabrian arc is a good example of the third model, with the Calabria-Peloritani block splitting away from Sardinia and Corsica (Alvarez et al., 1974) and acting as a rigid block which impinged on the southern Tethyan margin of Sicily and Italy during the Late Tertiary. The effect of this impingement was the thrusting of the platform and basinal carbonates onto the stable foreland of Apulia and Iblei, and the formation of an orocline. On a smaller scale, it is possible to see some effect of shear as the Peloritani block slides past the Sicilian region, causing the clockwise rotations seen in the thrust sheets of Sicily, while the reverse is seen to the northeast in Calabria.

The Umbrian and Wyoming arcs appear to have had a very similar history to that of the Calabrian arc, with impingement being the cause of bending. In the case of Umbria and Wyoming, there are no "foreign" blocks such as the Peloritani nappes to indent from behind, but the entire sections have been compressed and bent against the autochthonous foreland.

The two pronounced arcs within the Hercynian mountain belt both display a strong relationship in change of strike and declination which justify them to be called oroclines. The deformation, however, can be due to one or more of the following causes:

(1) Adjustment of microplates during their collision with the irregular margin of the cratonic Laurasian "Foreland" (Lorenz, 1976).

(2) Major dextral shear (Arthaud and Matte, 1977). 
(3) Paleo-east-west directed stresses.

(4) Indentation of Hercynian Europe by the irregular margin of Gondwana or by a Gondwana derived microplate (Lefort and Van der Voo, 1981).

The distribution of ophiolitic rocks, high pressure-low temperature metamorphism, nappe structures and paired metamorphic belts strongly suggests Britanny to be the location of major subduction and collision of a microplate with Armorica during Siluro-Devonian times. The post-Devonian bending of the Central European and Ibero-Armorican arcs therefore must be interpreted as a consequence of continued continental convergence during the final suturing between Gondwana and Laurasia during the Carbonifercus (Lefort and Van der Voo, 1981) in a tectonic setting analogous to the one proposed for the Himalayas and the peri-Himalayan region (Molnar and Tapponnier. 1977).

As a result of this study on a small number of oroclines, it must be concluded that the most probable mechanism for oroclinal deformation is the indentation of rigid crustal blocks into plastically-reacting, more or less unconsolidated fold belts. The role of indenter can be played either by promontory-like irregular continental margins (Channell et al., 1979) or continental blocks such as the Ebro-Aquitaine microplate (cf. Ziegler, 1984), which indented Hercynian Europe during the Carboniferous.

\section{REFERENCES}

Alterman, I.B., 1984. The orocline hypothesis versus thin skinned rotation in the central and southern Appalachians, Geophys. Res. Lell., 11: 88-89.

Alvarez, W., Cocozza, T. and Wezel. F.C., 1974. Fragmentation of the Alpine orogenic belt by microplate dispersal. Nature, 248: 309-314.

Argand, E., 1924. Tectonique de l'Asie. C.R. Congr. Géol. Int., 13e. 1922. Liège. pp. $171-372$.

Arthaud, F. and Matte, P., 1977. Late Paleozoic strike-slip faulting in southern Europe and north Africa; result of a right lateral shear zone between the Appalachians and the Urals. Geol. Soc. Am. Bull., 88; $1305-1328$.

Bachtadse, V.. 1984. Paläomagnetische Untersuchungen im Variszikum Mitteleuropas. Ph. D. thesis. Johannes-Gutenberg-Universität, Mainz, $143 \mathrm{pp}$.

Barberi, F., Civetta, L., Gasparini, P., Innocenti, F. and Scandone, R., 1974. Evolution of a section of the Africa-Europe plate boundary: paleomagnetic and volcanological evidence from Sicily. Earth Planet. Sci. Lett. 22: 123-132.

Beck, M.E., Jr., 1976. Discordant paleomagnetic pole positions as evidence of regional shear in the western Cordillera of North America. Am. J. Sci., 276: 694-712.

Beck, M.E.. Jr., 1980. Paleomagnetic record of plate-margin tectonic processes along the western edge of North America. J. Geophys. Res.. 85: 7115-7131.

Bernoulli, D. and Jenkyns, H.C., 1974. Alpine Mediterranean and Central Atlantic Mesozoic facies in relation to the early evolution of the Tethys. In: R.H. Dott and R.H. Shaver (Editors), Modern and Ancient Geosynclinal Sedimentation. Soc. Econ. Paleontol. Mineral., Spec. Publ., 19: 129-160.

Carey, S.W., 1955. The orocline concept in geotectonics. Proc. R. Soc. Tasmania, 89: 255-288.

Catalano, R.. Channell, J.E.T., D'Argenio, B. and Napoleone, G., 1976. Mesozoic paleogeography of the southern Apennines and Sicily. Mem. Soc. Geol. Ital.. 15: 95-118. 
Channell, J.E.T. and Tarling, D.H., 1975. Paleomagnetism and the rotation of Italy. Earth Planet. Sci. Lett. 25: 177-188.

Channell, J.E.T., Lowrie, W., Medizza, F. and Alvarez, W., 1978. Palaeomagnetism and tectonics in Umbria, Italy. Earth Planet. Sci. Lett., 39: 199-210.

Channell, J.E.T., D'Argenio, B. and Horvath, F., 1979. Adria, the African promontory in Mesozoic Mediterranean paleogeography. Earth Sci. Rev., 15: 213-292.

Channel, J.E.T., Catalano, R., and D'Argenio, B., 1980. Paleomagnetism and deformation of the Mesozoic continental margin in Sicily. Tectonophysics, 61: 391-407.

DeBouvier, M.C., Bonhommet, N. and Van der Voo, R., 1979. Paleomagnetism and K- ${ }^{40} \mathrm{Ar}$ dating of dolerite dikes from the Armorican Massif, France (abstr.). EOS, Trans. Am. Geophys. Union, 60: 220.

Demarest, H.H., Jr., 1983. Error analysis for the determination of tectonic rotation from paleomagnetic data. J. Geophys. Res., 88: 4321-4328.

Duff, B.A., 1979. The palaeomagnetism of Cambro-Ordovician red beds, the Erquy spillite series, and the Trégastel-Ploumanac'h granite complex, Armorican Massif (France and the Channel Islands). Geophys. J.R. Astron. Soc., 59: 345-365.

Duff, B.A., 1980. The palaeomagnetism of Jersey volcanics and dykes and the Lower Palaeozoic polar wander path for Europe. Geophys. J.R. Astron. Soc., 60: 355-373.

Edel, J.B. and Coulon, M., 1984. Late Hercynian remagnetization of Tournaisian series from the Laval syncline, Armorican Massif, France. Earth Planet. Sci. Lett., 68: 334-350.

Edel, J.B., Lacaze, M. and Westphal, M., 1981. Paleomagnetism in the northeastern Central Massif (France): evidence for Carboniferous rotations of the Hercynian orogenic belt. Earth Planet. Sci. Lett., 53: $48-52$.

Fisher, R.A., 1953. Dispersion on a sphere. Proc. R. Soc. London, Ser. A, 217: 295-305.

Fleming, R.S., Jr. and Sumner, J.R., 1975. Interpretation of geophysical anomalies over the arcuate Appalachians (abstr.). Geol. Soc. Am., Abstr. Progr., 7: 58.

French, A.N., 1978. Paleomagnetism and rock magnetism of the Rose Hill Formation. M.Sc. Thesis, University of Michigan, Ann Arbor, 66 pp.

French, A.N. and Van der Voo, R., 1979. The magnetization of the Rose Hill Formation at the classical site of Graham's fold test. J. Geophys. Res., 84: 7688-7696.

French, R.B., 1976. Lower Paleozoic magnetism of the North American Craton. Ph. D. Thesis, University of Michigan, Ann Arbor, $159 \mathrm{pp}$.

French, R.B. and Van der Voo, R., 1977. Remagnetization problems with the paleomagnetism of the middle Silurian Rose Hill Formation of the central Appalachians. J. Geophys. Res., 82: 5803-5806.

Gregor, G.B., Nairn, A.E.M. and Negendank, J.F.W., 1975. Paleomagnetic investigations of the Tertiary and Quaternary rocks: IX. The Pliocene of southeast Sicily and some Cretaceous rocks from Capo Passero. Geol. Rundsch., 64: 948-957.

Grubbs, K.L. and Van der Voo, R., 1976. Structural deformation of the Idaho-Wyoming overtlu ust belt (U.S.A.), as determined by Triassic paleomagnetism. Tectonophysics, 33: 321-336.

Hirt, A.M. and Lowrie, W., 1984. Paleomagnetism and tectonics in Umbria, Italy: new results from the Maiolica limestone (abstr.). Terra Cognita, 4: 371.

Hsü, K.J. and Bernoulli, D., 1978. Genesis of the Tethys and the Mediterranean. In: K.J. Hsü, and L. Montardet (Editors), Initial Reports of the Deep Sea Drilling Project. U.S. Government Printing Orfice, Washington, D.C., 42: 943-949.

Irving, E., 1977. Drift of the major continental blocks since the Devonian, Nature, 270: 304-309.

Johnson, R.J.E., Van der Voo, R. and Lowrie, W., 1984. Paleomagnetism and late Diagenesis of Jurassic Carbonates from the Jura Mountains, Switzerland and France. Geol. Soc. Am. Bull., 95: 478-488.

Jones, M., Van der Voo, R. and Bonhommet, N., 1979. Late Devonian to Early Carboniferous palaeomagnetic poles from the Armorican Massif (France). Geophys. J.R. Astron, Sóc., 58: 287-308.

Laubscher, H.P., 1961. Die Fernschubhypothese der Jurafaltung. Eclogae Geol. Helv., 54 (1): 221-282. 
Lefort, J.P. and Van der Voo, R., 1981. A kinematic model for the collision and complete suturing between Gondwanaland and Laurussia in the Carboniferous. J. Geol. 89: 537-550.

Lorenz, V., 1976. Formation of Hercynian subplates, possible causes and consequences. Nature, 262: $374-377$.

Lorenz, V. and Nicholls, I.A., 1984. Plate and intraplate processes of Hercynian Europe during the Late Paleozoic. Tectonophysics. 107: 25-56.

Lowrie, W. and Alvarez, W. 1975. Paleomagnetic evidence for rotation of the Italian Peninsula. J. Geophys. Res.. 80: 1579-1592.

McClelland Brown, E., 1983, Palaeomagnetic studies of fold development and propagation in the Pembrokeshire Old Red Sandstone. In: E. Mcclelland Brown and J. VanderBerg (Editors). Palaeomagnetism of Orogenic Belts. Tectonophysics. 98: 131-149

McElhinny, M.W., 1964. Statistical significance of the fold test in paleomagnetism. Geophys. J.R. Astron. Soc., 8: $338-340$.

Molnar, P. and Tapponnier, P., 1977. Relation of the tectonics of eastern China to the India-Eurasia collision: application of slipline field theory to large-scale continental tectonics. Geology. 5: 212-216.

Perrond, H., 1980. Contribution à l'étude paléomagnétique de l'are Ibéro-Armoricaine. Bull. Soc. Géol Minér. Bretagne, 14: 1-100.

Perroud, H. and Bonhommet, N., 1981. Palaeomagnetism of the Ibero-Armorican arc and the Hercynian orogeny in western Europe. Nature, 292: 445-448.

Perroud, H. and Bonhommet, N.. 1984. A Devonian paliteormagnetic pole for Armorica. Geophys. J.R. Astron. Soc., 77: 839--845

Perroud. H. and cobbold. P.. 1984. L'aimantation remanente comme marqueur de la déformation: exemple d'un pli à axe incliné dans les séries rouges siluro-devoniennes a Cabrillanes, Asturies (Espagne). Bull. Soc. Géol. Fr., 7: 169-184.

Perroud, H. and Van der Voo, R., 1985. Paleomagnetism of the Late Ordovician Thouars Massif, Vendée Province, France. J. Geophys. Res., in press.

Perroud. H.. Bonhommet. N. and Robardet, M., 1982. Comment on "A paleomagnetic study of Cambrian redbeds from Carteret. Normandy. France" by W.A. Morris. Geophys. J.R. Astron. Soc, 69: 573-578

Perroud. H., Bonhommet. $N$. and $V_{a}$ der $V_{0 o}, R ., 1983$. Paleomagnetism of the Crozon peninsula (France). Geophys. J.R. Astron. Soc.. 71: 307-320.

Perroud. H.. Robardet, M.. Van der Voo, R., Bonhommet, N. and Paris, F., 1985. Revision of the age of magnetization of the Montmartin redbeds, Normandy. France. Geophys. J.R. Astron. Soc., in press

Rankin, D.W., 1976. Appalachian salients and recesses: Late Precambrian continental breakup and the opening of the Iapetus Ocean. I. Geophys. Res., 81:5605-5619.

Ries. A.C.. 1978. The opening of the Bay of Biscay-- a review. Earth-Sci. Rev.. 14: 3563.

Ries, A.C. and Shackleton. R.M.. 1976. Patterns of strain variation in arcuate fold belts. Philos. Trans. R. Soc. London. Ser. A. 283:281-28k.

Rogers. J. 1975. Appalachian salients and recesses (abstr.). Geol. Soc. Am.. Abstr. Progr., 7: 111-112.

Roy, J.L., Opdyke. N.D. and Irving. E.. 1967. Further paleomagnetic results from the Bloomshurg Formation. I. Geophys. Res.. 72: 5075-5086.

Rutten, M.G., 1969. The Geology of Western Europe. Amsterdam. Elsevier. 520 pp.

Schult, A.. 1973. Paleomagnetism of Upper Cretaceous volcanic rocks in Sicily. Earth Planet. Sci. Lett. 19 $47-105$

Schult, A., 1976. Paleomagnetism of Cretaceous and Jurassic volcanic rocks in west Sicily. Earth Planet Sci. Lett. 31: 454-457.

Schwartz, S.Y. and Van der Voo, R.. 1983. Paleomagnetic evaluation of the orocline hypothesis in the central and southern Appalachians. Geophys. Res. Lett., 10: 505-508.

Schwartz. S.Y. and Van der Voo. R., 1984. Paleomagnetic study of thrust sheet rotation during foreland impingement in the Wyoming-Idaho overthrust belt. J. Geophys. Res., 89: 10077-10086. 
Steiner, M.B. and Helsley, R., 1975. Reversal pattern and apparent polar wander for the Late Jurassic. Geol. Soc. Am. Bull., 86: 1537-1543.

Thomas, W.A., 1977. Evolution of Appalachian-Ouachita salients and recesses from reentrants and promontories in the continental margin, Amer. J. Sci., 277: 1233-1278.

VandenBerg, J. and Wonders, A.A.H.. 1976. Paleomagnetic evidence of large fault displacement around the Po Basin. Tectonophysics, 33: 301-320.

VandenBerg, J. and Zijderveld, J.D.A., 1982. Paleomagnetism in the Mediterranean area. In: H. Berckhemer and K. Hsü (Editors), Alpine-Mediterranean Geodynamics. Gendyn. Ser., 7: 83-112.

Vanden Berg, J., Klootwijk, C.J. and Wonders, A.A.H., 1978. The Late Mesozoic movements of the Italian peninsula: further paleomagnetic evidence from the Umbrian sequence. Bull. Geol. Soc. Am., 89: $133-150$.

Van der Voo, R., 1967. The rotation of Spain: paleomagnetic evidence from the Spanish Meseta. Palaeogeogr., Palaeoclimatol., Palaeoecol., 3: 417-432.

Van der Voo, R., 1969. Paleomagnetic evidence for the rotation of the Iberian peninsula. Tectonophysics, 7: $5-56$.

Van der Voo, R. and Channell, J.E.T., 1980. Paleomagnetism in orogenic belts. Rev. Geophys. Space Phys., 18: 455-481.

Van der Voo, R. and French, R.B., 1974. Apparent polar wandering for the Atlantic bordering continents: Late Carboniferous to Eocene. Earth Sci. Rev., 10: 99-112.

Van der Voo, R. and French, R.B., 1977. Paleomagnetism of the Late Ordovician Juniata Formation and the remagnetization hypothesis. J. Geophys. Res., 82: 5796-5802.

Van der Voo, R. and Klootwijk, C.T., 1972. Paleomagnetic reconnaissance study of the Flamanville granite, with special reference to the anisotropy of its susceptibility. Geol. Mijnbouw, 51: 609-617.

Van der Voo, R. and Zijḍerveld. J.D.A., 1969. Paleomagnetism in the western Mediterranean area. Verh. K. Ned. Geol. Mijnbouwk. Genoot., Geol. Ser., 26: 121-138.

Van der Voo, R., French, A.N. and French, R.B., 1979. A paleomagnetic pole position from the folded Upper Devonian Catskill red beds, and its tectonic implications. Geology, 7: 345-348.

Windley, B.F., 1984. The Evolving Continents. Wiley, New York, 399 pp.

Ziegler, P.A., 1984. Caledonian and Hercynian crustal consolidation of Western and Central Europe-a working hypothesis. Geol. Mijnbouw, 63: 93-108.

Zwart, H.J. and Dornsiepen, U.F., 1978. The tectonic framework of Central and Western Europe. Geol. Mijnbouw, 57: 627-654. 